
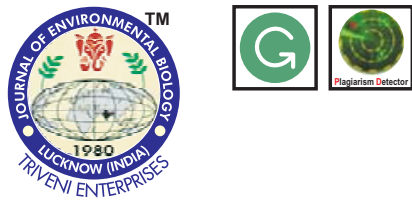

\title{
Fresh water planktonic algae from oligotrophic habitat of West Bengal with special remarks on taxonomy and ecology
}

\section{Authors Info}

J.P. Keshri', A.K. Ghosh", S. Ghosh', S. Roy' and A. Chakraborty ${ }^{2}$

'Phycology Research Lab, Department in Botany (UGC - CAS), The University of Burdwan, Golapbag, Burdwan-713 104, India

${ }^{2}$ Birbal Sahni Institute of Palaeosciences, 53 University Road, Lucknow-226 007, India

*Corresponding Author Email : akghosh_in@yahoo.com

\section{Key words}

Fresh water Oligotrophic Planktonic algae

SEM studies

West Bengal

\section{Publication Info}

Paper received : 29.04.2017

Revised received : 29.06.2017

Re-revised received : 12.07 .2017 Accepted : 04.08.2017

\section{Abstract}

Aim : Taxonomic analysis of fresh water phytoplankton based on bright field microscopy and SEM studies is yet to be done in depth that may elucidate a number of new taxa. The present study on the assemblage of fresh water phytoplankton is focused to interpret the ecological condition of the studied water body of Bankura District in West Bengal.

Methodology : Phytoplankton samples were collected from water bodies of Bankura District, West Bengal during the winter season. Planktonic algal taxa were analyzed using Scanning Electron Microscopy after preliminary observations made under Bright Field Microscopy. Qualitative and quantitative analyses of the phytoplankton were done for accurate taxonomic assignment of the taxa and interpretation of ecological perspectives.

Results : The qualitative analysis revealed an assemblage of phytoplankton that includes ten taxa. In the present assemblage, euglenophytes are represented by only one species, whereas, five species of desmids belonging to three genera and four species of diatoms belonging to four genera have been identified and illustrated. Quantitatively amongst the different groups of phytoplankton, desmids are dominant (57\%) followed by diatoms (40\%) with a minor representation of euglenophytes (3\%).

Interpretation: The qualitative and quantitative analyses of the phytoplankton assemblage indicate an oligotrophic condition.

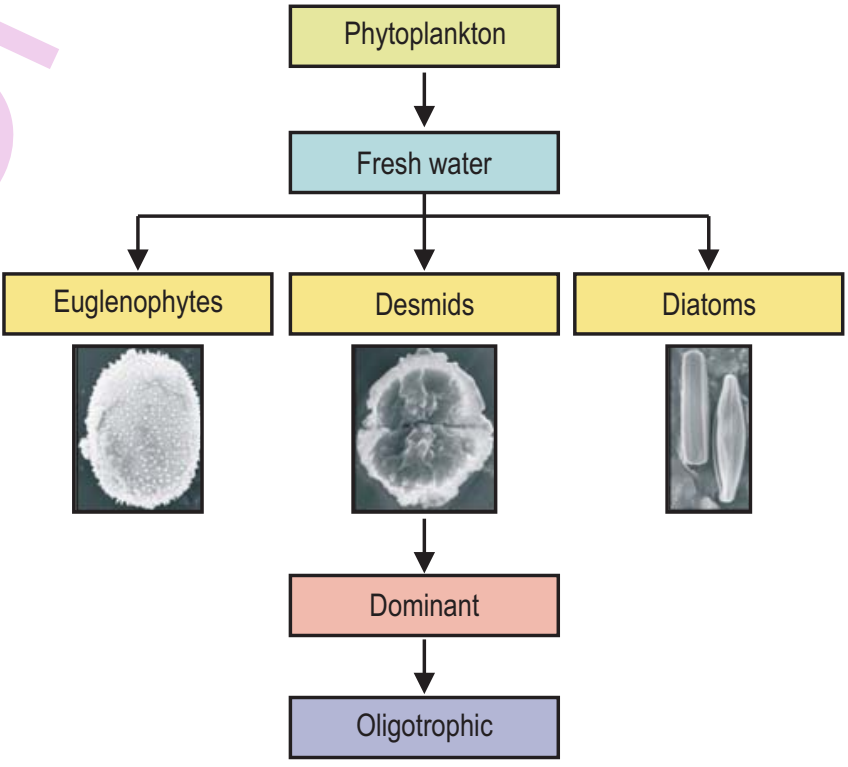




\section{Introduction}

Owing to the existence of a great variety of geological, topographical, ecological and micro-climatic conditions, the Indian sub-continent is remarkably rich in its water resources. In India, there are large number of natural pools and ponds at different geographical locations in different altitudes having variable climatic conditions. Studies on fresh water algae are mainly focused to the algal biodiversity. Extensive study concerning various aquatic habitats and its ecological perspectives has not been carried out in depth. Organisms living in aquatic habitats are one of the most reliable indicators of water quality. In view of this, observation on the algal flora in aquatic habitat are needed for the study of water quality because these organisms can be used as indicators of water pollution. Though studies on fresh water planktonic algae, specifically diatoms have been carried out from different regions of India (Senthilkumar and Sivakumar, 2008; Karthick et al., 2013), some areas are still unexplored. Planktonic algae viz., desmids and diatoms significantly contribute towards the maintenance of water quality. In recent years, biodiversity in freshwater environments are receiving unique attractions as the issues related to biodiversity in aquatic ecosystem has been incorporated in the programme of UNESCO and the International Union of Biological Sciences. Identification of the phytoplankton can be done by light microscopic study. However, for proper identification and Scanning Electron Microscopic (SEM) studies are essential. Otherwise, wrong identification of the taxa may lead to erroneous environmental interpretations. In India, SEM studies on fresh water phytoplankton have been done very sparingly (Vidyavati, 1995; Senthilkumar and Sivakumar, 2008; Karthick and Kociolek, 2011; Keshri et al., 2016; Roy and Keshri, 2016). During the present investigation, the authors recorded a number of fresh water planktonic algae from the Bankura District of West Bengal; those have been studied under SEM. Some of the reported taxa were not known earlier from India or as a new record from the state of West Bengal. The present study is aimed to interpret the habitat and ecological condition of fresh water planktonic algae with remarks on the taxonomic analysis.

\section{Materials and Methods}

Bankura District in the state of West Bengal is the connecting link between the plains of Bengal on the east and Chotanagpur plateau on the west. The district is situated between $22^{\circ} 38^{\prime}$ and $23^{\circ} 38^{\prime} \mathrm{N}$ and between $86^{\circ} 36^{\prime}$ and $87^{\circ} 46^{\prime}$ E. The climate, especially in the upland tracts to the west is much drier than in eastern or southern Bengal. From the beginning of March to early June, hot westerly winds prevail, and the temperature rise around $45^{\circ} \mathrm{C}$. The monsoon season (during June to September) is comparatively pleasant. It has been recorded that the total average rainfall is about $1,400 \mathrm{~mm}$. During the winter months (i.e., December to January) the temperature drops down to below $27^{\circ} \mathrm{C}$.
The samples of phytoplankton were collected in the winter months (January-February) in two successive years from different ponds of Kotulpur area of Bankura District, West Bengal (Fig. 1). The techniques modified after Krammer and LangeBertalot (2000) was followed for processing of the samples. One part of the sample was preserved in $5 \%$ formalin prepared from paraformaldehyde crystals and another part was preserved in $70 \%$ ethanol for diatom preservation. Sub-samples (preserved in $70 \%$ ethanol) were cleaned using $30 \%$ hydrogen peroxide. The organic coating was removed and the clean samples were then repeatedly centrifuged at 3000-3200 rpm and alternatively rinsed with distilled water for 3-4 times. Using standard protocol, microscopic slides were prepared. Bright-field microscopic study was carried out for preliminary identification and qualitative analysis. Systematic descriptions and identification of the planktonic algae have been done using standard monographs and available literature. Phytoplankton cell counts from the composite samples were performed using a Sedgewick-Rafter cell counter for quantitative analysis. Phytoplankton abundance was deduced based on the counting of 200 specimens. Quantitative analysis of the recorded taxa was also carried out using Microsoft Excel 2007. For SEM studies the samples were fixed in $2.5 \%$ glutaraldehyde and $0.1 \%$ phosphate buffered saline (PBS) for 2 hours. Later on, the samples were rinsed with PBS for 10 minutes and dehydrated in a graded series of alcohols. Subsequently they were placed in $100 \%$ acetone and dried. Specimens were then coated with gold. Photographs of detailed morphological structures were taken using LEO 430 Scanning Electron Microscope (SEM) using accelerating voltage of $15 \mathrm{KV}$ and a working distance of 24-34 $\mathrm{nm}$ at Birbal Sahni Institute of Palaeosciences, Lucknow.

\section{Results and Discussion}

Qualitative analysis of the phytoplankton under bright field microscopy and SEM reveals the occurrence of three important groups of phytoplankton i.e., Euglenophyta, Chlorophyta and Bacillariophyta.

The Euglenophyta is represented by a solitary taxon Trachelomonas klebsii Deflandre (Fig. 2A). It is characterized by oval lorica, broadly rounded, punctate and densely covered with short spines, apical pore surrounded by a ring like thickening. It measures $24 \mu \mathrm{m}$ in diameter and $40 \mu \mathrm{m}$ in length. The taxon is distributed in Gujarat (Kamat, 1961) and Maharashtra (Kamat, 1968, 1975), however, it is reported for the first time from West Bengal.

The chlorophytes belonging to Order Zygnematales (Family Desmidiaceae) includes three species of the genus Cosmarium and one species each of the genera Haplotaenium and Euastrum.

The diagnostic features of Cosmarium quadrum Lundell var. sublatum (Nordstedt) West et. West (Fig. 3A) are: cells 


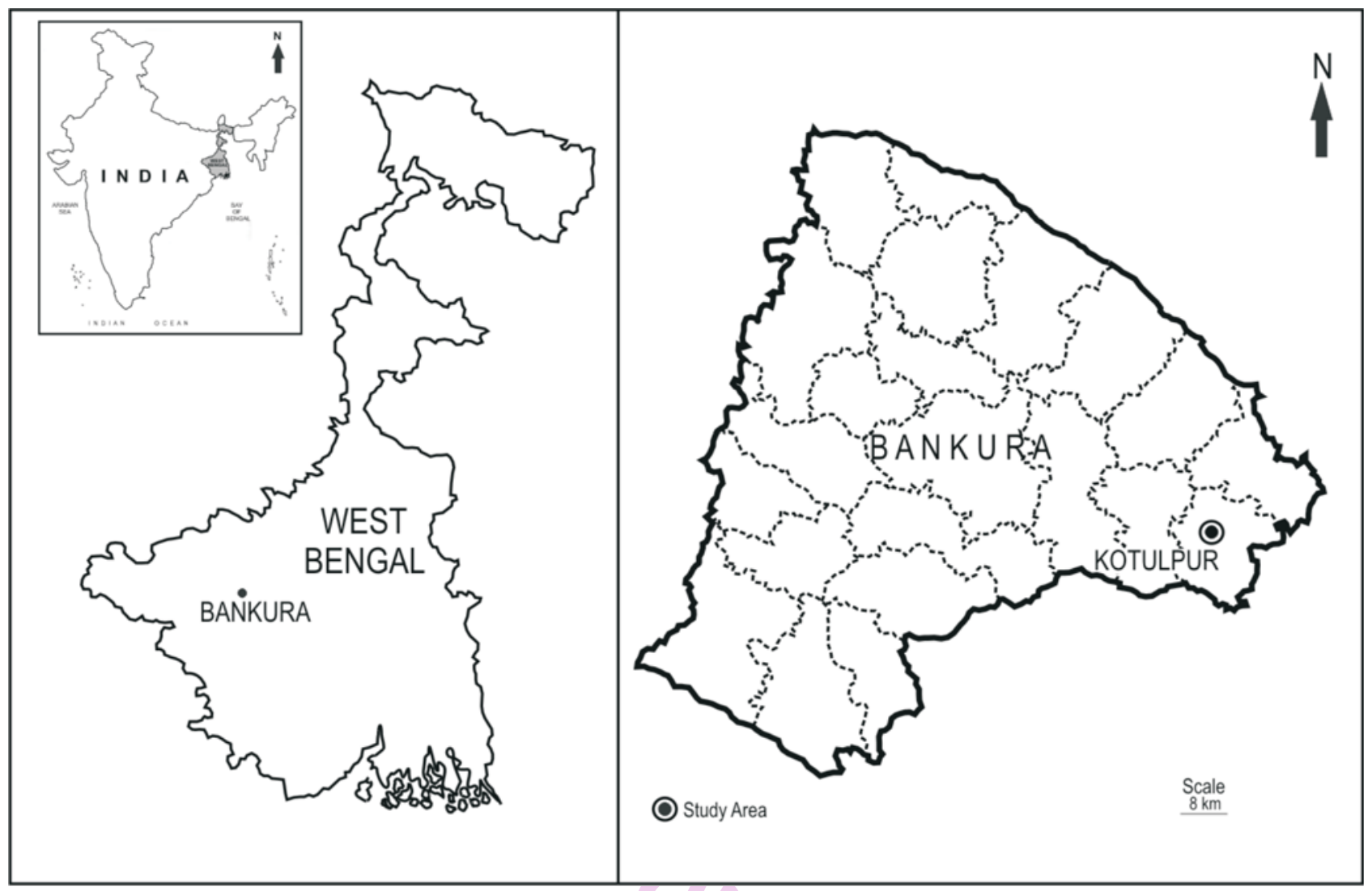

Fig. 1 : Map showing the study area and sampling site in Bankura District of West Bengal State, India

slightly longer than broad, median constriction deep, sinus linear; semi-cells rectangular, apex slightly retuse; cell wall with densely and regularly arranged granules; in between the granules number of pores present, measuring 36-45 $\mu \mathrm{m}$ broad, $42-50 \mu \mathrm{m}$ long and isthmus 10-12 $\mu \mathrm{m}$. This is the first report of the taxon from India and it is common in the present assemblage.

Cosmarium pakistanicum Islam (Fig. 2F) is characterised by cells having dimension two times longer than broad, median constriction deep, semi-cells elliptic, apex round, wall with puncta, measuring 56-70 $\mu \mathrm{m}$ broad and 90-120 $\mu$ m long, apex 30 $\mu \mathrm{m}$, isthmus $42-45 \mu \mathrm{m}$. This species of the genus Cosmarium is reported here for the first time from India.

The significant taxonomic features of Cosmarium connatum (Bréb.) Ralfs (Fig. 2B) are: cell length greater than width; median constriction shallow, sinus widely open, semi-cells sub-elliptic, apex slightly flattened; poles rounded, smooth walled, dimension: $42-47 \mu \mathrm{m}$ in breadth and 65-73 $\mu \mathrm{m}$ in length, isthmus $36-39 \mu \mathrm{m}$. This species is widely distributed in Maharashtra (Freitas and Kamat, 1979), Madhya Pradesh (Agarkar et al., 1979), Andaman and Nicobar Islands (Prasad and Misra, 1992), Kerala (Sindhu and Panikkar, 1995), Sikkim and West Bengal (Santra and Pal, 2006).
The genus Haplotaenium of family Desmidiaceae is represented by $\mathrm{H}$. minutum (Ralfs) Bando (Fig. $2 \mathrm{H}$ ). Its important identifying characters are: cells cylindrical, straight, slender, more than eight times longer than breadth; median incision shallow, poles truncate, apices without tubercles; semi-cells with single basal inflation, chloroplast single, axial, pyrenoids many in linear pattern, cells measure 70-80 $\mu \mathrm{m}$ long and 3-6 $\mu \mathrm{m}$ broad, apex 4$5 \mu \mathrm{m}$ in width. This is comparatively a rare taxon and this species of genus Haplotaenium is the first report from India.

Euastrum inerme (Ralfs) Lund. var. depressum Wolle (Fig. 2C) belonging to family Desmidiaceae possesses small cells, which are broadly oval in outline, semi-cells truncate, pyramidal to semi-oval in outline, converging lateral margins with conspicuous undulation halfway to the apex, apex more or less truncate with a very short median incision, cells $16-20 \mu \mathrm{m}$ broad and 22-28 $\mu \mathrm{m}$ long. This species was not known earlier from India.

The diatoms (Bacillariophyta) belonging to the Order Pennales includes four species of the genera Encyonema, Stenopterobia, Brachysira and Ulnaria.

Encyonema neogracile Krammer (Fig. 2G) is characterized by asymmetrical valves, semi-lanceolate, strongly 

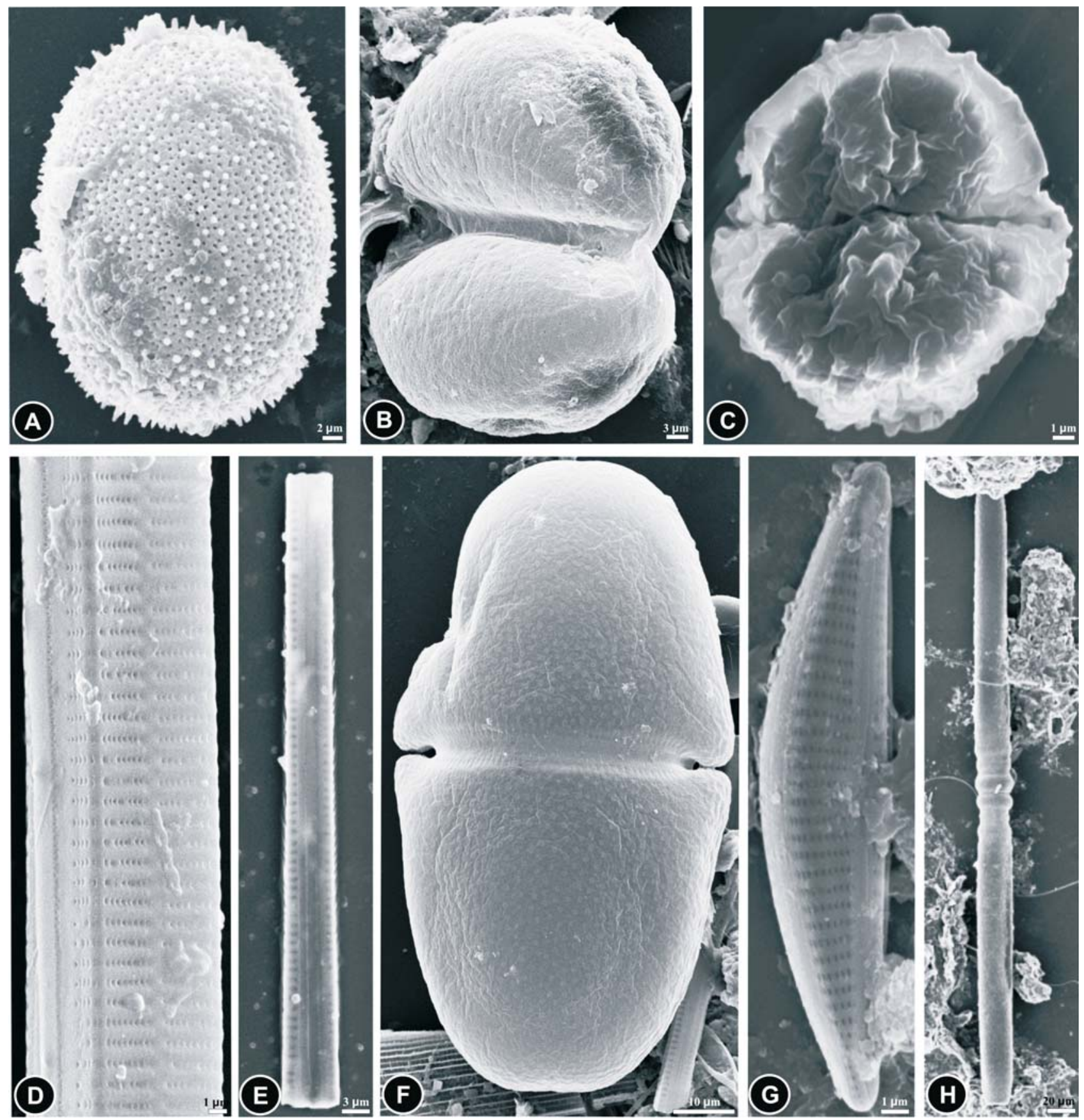

Fig. 2 : SEM photomicrographs for morphological structure of fresh water phytoplankton (A) Trachelomonas klebsii Deflandre (B) Cosmarium connatum (Bréb.) Ralfs (C) Euastrum inerme (Ralfs) Lund. var. depressum Wolle (D-E) Ulnaria ulna (Nitzsch) Compère (F) Cosmarium pakistanicum Islam (G) Encyonema neogracile Krammer (H) Haplotaenium minutum (Ralfs) Bando

dorsiventral, dorsal margin convex and more or less straight ventral margin, apex of valve bluntly rounded, $27-33 \mu \mathrm{m}$ long and 5.66-6.25 $\mu \mathrm{m}$ wide; raphe thin and straight, axial area narrow and linear, central area small, asymmetrical, larger on the dorsal side; striae parallel to somewhat radial. Its distribution is mainly confined to Maharashtra (Gandhi, 1960) and Assam (Phukan and
Bora, 2012; Buragohain et al., 2012). This is the first report of the taxon from West Bengal as well as from eastern India.

Important taxonomic features of Stenopterobia sigmatella (Gregory) Ross (Fig. 3B-C) are: sigmoid solitary cells with elongated valves, end portion gradually becomes narrow 

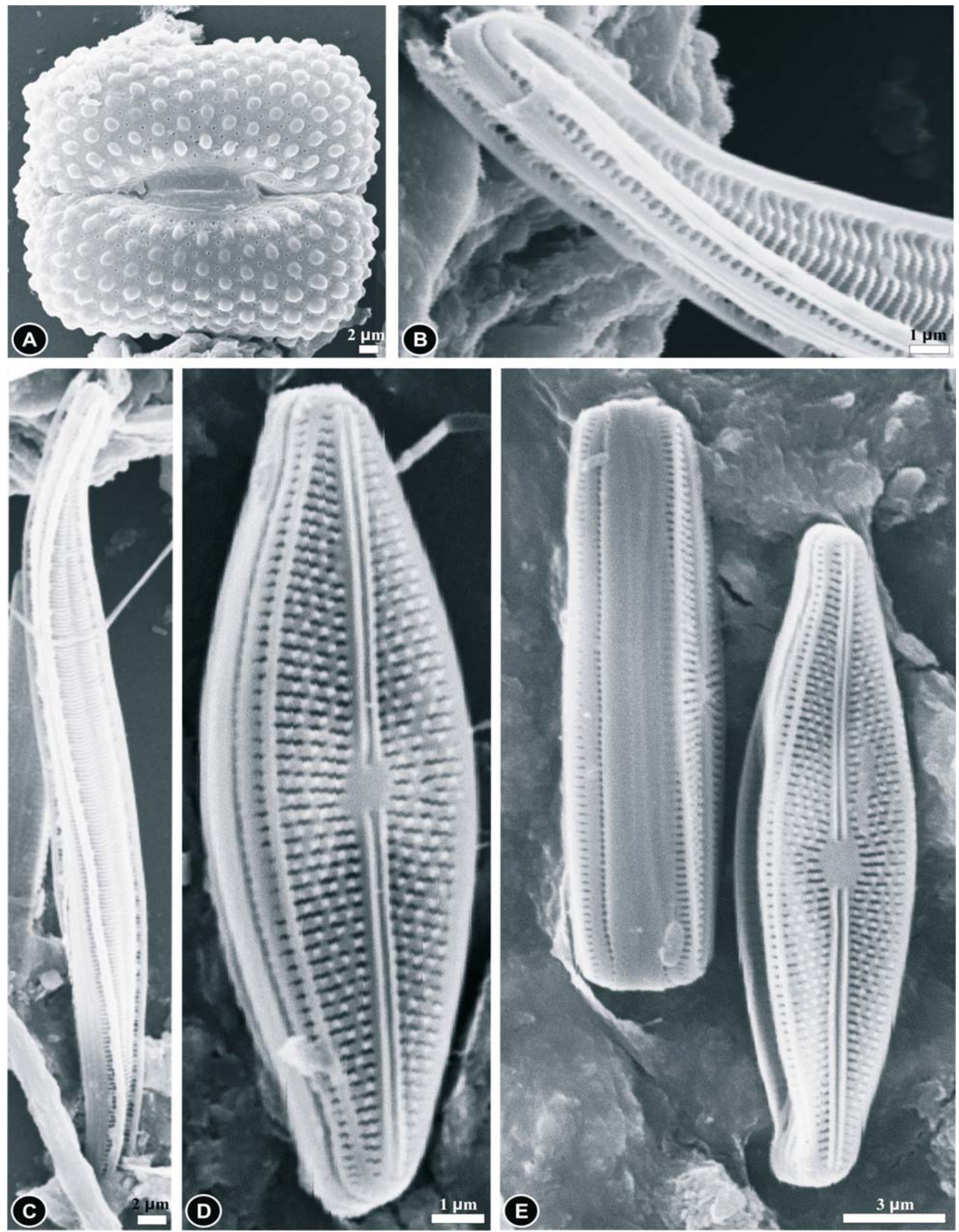

Fig. 3: SEM photomicrographs for morphological structure of fresh water phytoplankton- (A) Cosmarium quadrum Lundell var. sublatum (Nordstedt) West et. West (B-C) Stenopterobia sigmatella (Gregory) Ross (D-E) Brachysira microcephala (Grunow) Compère. 
with bluntly rounded apex, 30-32 $\mu \mathrm{m}$ long and 3-4 $\mu \mathrm{m}$ wide, slight undulation found in valve face, fibulate raphe system found, fibulae are formed partially by the infolding and fusion of parts of valve face with mantle, striae delicate, multiseriate, pseudoraphe present. Stenopterobia sigmatella occurs in brackish water and epipelic freshwater habitats, however, Desikachary (1989) reported this species from Indian Ocean. This species is hereby recorded for the first time from freshwater habitat of India.

The diatom taxon Brachysira microcephala (Grunow) Compère (Fig. 3D-E) is distinguishable by rhombic to lanceolate valves with protracted apices, measuring 15.6-19.17 $\mu \mathrm{m}$ long and 3.8-4.32 $\mu \mathrm{m}$ wide; axial area narrow and straight; central area small; striae are radiate near the central region and parallel near apices, stria density is $25-27$ in $10 \mu \mathrm{m}$; straight raphe was placed in between two ribs that lie on the external face of the valve. It is distributed in different parts of peninsular India (Karthick et al., 2013), though, it was not known earlier from eastern India as well as from West Bengal.

Distinguishing features of Ulnaria ulna (Nitzsch) Compère (Fig. 2D-E) are: valves solitary, linear, much elongated, gradually attenuated to the rostrate ends, pseudoraphe distinct, narrow, widening towards centre; central area quadrangular having small lineate striae on both margins, length 80-100 $\mu \mathrm{m}$ and width 5 to $6 \mu \mathrm{m}$, distribution of striae $12-15$ in $10 \mu \mathrm{m}$. This is a commonly occurring species of diatom distributed in different regions of India (Roy and Keshri, 2016). Its presence in the presently analyzed phytoplankton assemblage is more or less common.

Quantitative analysis carried out in the present study reveals that amongst the different groups of phytoplankton desmids are dominant $(57 \%)$, followed by diatoms (40\%). The euglenophytes are very poorly represented $(3 \%)$ by a solitary species i.e., Trachelomonas klebsii. The genus Cosmarium is most preponderant in the assemblage and is represented by three species, out of which Cosmarium quadrum var. sublatum that constitutes $13.65 \%$ of the total phytoplankton assemblage. However, frequency of occurrence of the desmid taxon Euastrum inerme var. depressum is most dominant (15.60\%) amongst all the phytoplankton in the present assemblage. Diatoms are represented by four species out of which Encyonema neogracile is the most frequently occurring form (13.17\%).

As evident from this study, desmids are the dominant group of phytoplankton followed by diatoms and euglenophytes. This signifies the oligotrophic condition, since desmids prefer to grow in oligotrophic waters (Shashikanth and Anand, 1978). Similarly, the presence of particular diatom taxa viz., Stenopterobia sigmatella, Brachysira microcephala is also indicative of an oligotrophic condition (Bellinger and Sigee, 2015; Faustino et al., 2016). The euglenophyte taxon Trachelomonas klebsii recorded in the present assemblage is found in low frequency. The species was reported for the first time from West Bengal and eastern India. Euglenophytes typically grow in eutrophic water and they are often considered as bioindicators of water contamination (Starmach, 1983; Wołowski, 2011), however, in the present study, a non-pollution indicating taxon Trachelomonas klebsii has been observed in oligotrophic waters with good cosmos of desmids and diatoms. Although this specific euglenophyte is unpolluted in nature, the presence of euglenophytes may lead to the mesotrophic condition.

In the present assemblage, some of the taxa are common to India and specifically from West Bengal. However, some of the taxa are new to this part of eastern India as well as West Bengal (e.g., Trachelomonas klebsii Deflandre, Encyonema neogracile Krammer and Brachysira microcephala (Grunow) Compère). From India Cosmarium quadrum Lundell var. sublatum (Nordstedt) West et. West, Cosmarium pakistanicum Islam, Haplotaenium minutum (Ralfs) Bando and Euastrum inerme (Ralfs) Lund. var. depressum Wolle have been recorded here for the first time. Quantitatively amongst the diatoms, Encyonema neogracile Krammer and Ulnaria ulna (Nitzsch) Compère are commonly occurring, whereas, Brachysira microcephala (Grunow) Compère is comparatively less in abundance. Amongst all the diatoms Stenopterobia sigmatella (Gregory) Ross is rare and reported for the first time from freshwater habitat. The desmids are represented by five taxa out of which, Euastrum inerme (Ralfs) Lund. var. depressum Wolle and Cosmarium quadrum Lundell var. sublatum (Nordstedt) West et. West are dominant, whereas, other taxa viz., Cosmarium connatum (Bréb.) Ralfs, Cosmarium pakistanicum Islam and Haplotaenium minutum (Ralfs) Bando are more or less common.

The species richness, as well as dominance of desmids is indicative of a low nutrient condition (Tiseer et al., 2008). In fresh water environments where the ionic composition is reduced, population of desmids becomes more preponderant (Kadiri, 1996, 1999; Nwankwo, 1996). In dry season when precipitation is low, the presence of more number of species of desmids and diatoms in a water body is common (Whitton et al., 1991). Samples for the present study were collected during the winter season, and apparently during this season dry condition prevails, and precipitation becomes weak. Thus, the present phytoplankton assemblage clearly indicates an oligotrophic state as it is dominated by desmids and some characteristic diatoms which prefer to grow in oligotrophic waters. The planktonic assemblage recovered in this study is very fascinating from both taxonomic and ecological point of view. It is very significant because many rare diatoms have been recorded in this analysis. It represents a long undistributed geological history of the area that is supported by suitable habitats for speciation. 


\section{Acknowledgments}

Special thanks are due to our revered teacher Prof. Pranjit Sarma (retired), Department of Botany, The University of Burdwan (West Bengal, India) for his constant encouragement. The financial assistance provided by the UGC and laboratory facilities provided by the Head, Department of Botany; The University of Burdwan are gratefully acknowledged. Sincere thanks are also due to Professor Sunil Bajpai, Director, Birbal Sahni Institute of Palaeosciences, Lucknow for SEM and other facilities (Permission No. BSIP/RDCC/Publication No. 19/201516). One of us (A.C) is indebted to DST for the DST-INSPIRE Fellowship (IF-120842).

\section{References}

Agarkar, D.S., M.S. Agarkar and R. Dixit: Desmids from Bandhavgarh, Madhya Predesh, India. Hydrobiologia, 65, 213-223 (1979).

Bellinger, E.G. and D.C. Sigee: Freshwater Algae: Identification, Enumeration and Use as Bioindicators. John Wiley \& Sons, Inc., Hoboken, NJ, USA. Doi: 10.1002/9781118917152.ch1 (2015).

Buragohain, B.B., Y. Farista and N.K. Brahma: Epilithic algal flora of Samaguri Lake, India: Asystematic approach on algae-I. Annals of Biol. Res., 3, 4808-4819 (2012).

Desikachary, T.V.: Marine diatoms of the Indian Ocean region. In: Atlas of diatoms Fasc. VI (Ed.: T.V. Desikachary), Madras Science Foundation, Madras, India, pp. 1-27 (1989).

Faustino, S.B., L. Fontana, E.C.R. Bartozek, C.E.M Bicudo and D.C. Bicudo: Composition and distribution of diatom assemblages from core and surface sediments of a water supply reservoir in Southeastern Brazil. Biota Neotropica, 16, e20150129. http://dx.doi.org/10.1590/1676-0611-BN-2015-0129 (2016).

Freitas, J.F. and N.D. Kamat: Desmidaceae of Nagpur. Phykos, 18, $97-$ $103(1979)$.

Gandhi, H.P.: On the diatom flora of some ponds around Vasna village near Ahmedabad. J. Indian Bot. Soc., 39, 558-567 (1960).

Kadiri, M.O.: More desmids from the Ikpoba reservoir (Nigeria) compared with other records from Africa. Algological Stud., 80, 8798 (1996).

Kadiri, M.O.: Phytoplankton distribution in the coastal areas of Nigeria. Nig. J. Bot., 12, 51-62 (1999).

Kamat, N.D. and R. Aggarwal: Diatoms from Nainital. J. Bombay Nat. Hist. Soc., 72, 240-241 (1975).

Kamat, N.D.: Algae of Alibag, Maharashtra. J. Bombay Nat. Hist. Soc., 65, 88-104 (1968).

Kamat, N.D.: The Euglenophyceae of Ahmedabad, India. J. Univ. Bombay, 30, 15-21 (1961).
Karthick, B. and J.P. Kociolek: Four new centric diatoms (Bacillariophyceae) from the Western Ghats, South India. Phytotaxa, 22, 25-40 (2011).

Karthick, B., P.B. Hamilton and J.P. Kocilek: An illustrated guide to common diatoms of Penninsular india. Gubbi Labs, Gubbi (2013).

Keshri, J.P., A.K. Ghosh and S. Roy: On the occurrence of four diatom taxa from eastern India with a taxonomic Note. J. Bot., 2016, Article ID 1039265, 5 pages. Doi: 10.1155/2016/1039265 (2016).

Krammer, K. and H. Lange-Bertalot: Bacillariophyceae. In: Süsswasserflora von Mittleuropa, (Eds.: H. Ettl, J. Gerloff, H. Heynig and D. Mollenhauer), Spektrum Akademischer, Heidelberg, Germany, pp. 1-610 (2000).

Nwankwo, D.I.: Fresh water swamp desmids from south Niger Delta, Nigeria. Polkie Archiwum Hydrobiologii, 43, 411-420 (1996).

Phukan, S. and S.P. Bora: Preliminary report of diatom from Sivsagar district of Assam. Ind. J. Fund. Appl. Sci., 2, 55-61 (2012).

Prasad, B.N. and P.K. Misra: Freshwater algal flora of Andaman and Nicobar Islands. Vol. 2, Bishen singh and Mahendra Pal Singh Publ., Dehradun, p. 284 (1992).

Roy, S. and J.P. Keshri: Studies on four araphid taxa (Bacillariophyta) from Srikhola River, Eastern Himalaya. Phykos, 46, 7-16 (2016).

Santra, S.C. and U.C. Pal: Desmid flora of eastern India: Sikkim and West Bengal. In: Recent trends in Algal Taxonomy: Taxonomic and Cultural Studies (Eds.: Vidyavati and A.K. Mahato). Vol. 2, Associate Publishing Company, New Delhi, pp. 409-513 (2006).

Senthilkumar, R. and K. Sivakumar: Studies on phytoplankton diversity in response to abiotic factors in Veeranam lake in the Cuddalore district of Tamil Nadu. J. Environ. Biol., 29, 747-752 (2008).

Shashikanth and V.K. Anand: Interrlationships of phytoplankton and physical factors in Mansar lake Jammu (J \& K). Indian J. Ecol., 5, 134-140 (1978).

Sidhu, P. and M.V.N. Panikkar: Desmids new to Kerala, India-I. Feddes Repertorium, 106, 317-323 (1995).

Starmach K.: Euglenophyta - Eugleniny, Flora Słodkowodna Polski. Polska Akademia Nauk, Instytut Botaniki. Vol. 3, Polskie Wydawnictwo Naukowe, Krakow, p. 563 (1983).

Tiseer, F.A., Y. Tanimu and A.M. Chia:Seasonal occurrence of algae and physicochemical parameters of Samaru Stream, Zaria, Nigeria. Asian Jour. Ear. Sci., 1, 31-37 (2008).

Vidyavati: Glimpses in Phycology. Jain Brothers, New Delhi (1995).

Whitton, B.A., E. Rott and G. Friendrich: Use of algae for monitoring rivers. Proc. Int. Symp. Dusseldorf. Germany, pp. 1-193 (1991).

Wolowski, K.: Phylum Euglenophyta (Euglenoids). In: The freshwater Algal Flora of the British Isles. An Identification Guide to Freshwater and Terrestrial Algae (Eds.: D.M. John, B.A. Whitton and A.J. Brook), Second Edn., Cambridge University Press, Cambridge, pp. 181-239 (2011). 